\title{
Violation of Building Bye-Laws and Development Control Rules: A Case Study
}

\author{
${ }^{1}$ T.N.Boob, ${ }^{2}$ Dr. Y.R.M. Rao \\ ${ }^{I}$ Principal, Dr.N.P.Hirani Polytechnic, Pusad Dist.- Yavatmal (M.S.) \\ ${ }^{2}$ Principal, Dr. Pauls Engineering College, Vanur Tk, Villupuram Dist, Tamilnadu
}

\begin{abstract}
Due to the inherent migration of rural population to urban areas, towns are developing very rapidly. For every municipal council, Development Control Rules and Building Bye-laws are framed as per Maharashtra Regional and Town Planning Act 1966. It is obligatory on the part of every individual who desires to construct a structure to obtain necessary permission from the local authority before proceeding for construction. In spite of rules and regulations framed for good reasons, instances of violation of development control rules are observed. As a result, the development of town experiences haphazard and unplanned urbanization. This paper presents the critical analysis of development control rules which are violated at large. An attempt has been made to find the factors for such violation of these rules. The scope of the study is limited to residential constructions. Class " $B \& C$ " municipal councils of Yavatmal district of Maharashtra state (India) which is a progressive district in terms of development has been identified for this case study. It is expected that recommendation like three-tier real time information and control system, violation reducing mechanism presented will inspire new initiatives and stimulate debate in the often neglected area of urban development control rules \& regulations.
\end{abstract}

Keywords: - Violation, building regulation, building permission, development control rules, floor space index.

\section{Introduction:}

Municipal council is the legitimate authority to prepare land use plan; it takes care of plan implementation, controls the development and manages the growth of town. The main aim is to ensure plan development, promoting healthy urban environment, reducing congestion and crowd, preventing development of conflicting land use and at micro level violation of building control rules during construction etc., to ensure a sustainable development of a town.

The government officials, geographers, environmentalists, architects, consultants, builders and developers generally agree that some form of control is necessary to guide the growth, in order to ensure adequate public services and to protect public health and safety.

Sustainable environment is possible by an assortment of standards and regulations. These standard rules and regulations provide an important and inescapable framework from the formation of subdivision to the control of storm water runoff. Regulations for the sustainable environment are as old as Indian civilization. Instances of violation of development control rules are no doubt just as old. The subject of regulations leads to the source of how communities have been designed and built -how they can build or cannot and how these controls continue to shape the physical space in which we live and work. [1]

Mainly such laws are State legislations as the state is competent to legislate and make laws on such subjects. However, where the central government is to legislate on such subjects and where the parliament is to make law on its behalf, such legislations are applicable in the union territories and in the state such as Delhi, where land uses are reserved with the Government of India. One such central legislation is Delhi Development Act, 1957. For other states, such central laws are advisory and recommendatory in nature. Taking this legislation as model, other state governments formulate the rules and regulations with the help of local bodies, under the various legislations. After the approval, the local bodies concerned enforce these rules and regulations pertaining to development and building standards as building regulations and building bye-laws in their respective areas.[2]

Building regulations and bye-laws provide the mandatory techno-legal framework for regulating building activity from planning, design to completion of construction.

Accordingly standardized building bye-laws and development Control rules for Class A, B, C Municipal Council of Maharashtra State are framed under the Maharashtra Municipalities Act 1965 \& Maharashtra regional and town planning Act, 1966 and those are published. These bye-laws are amended from time to time taking in to account the National building code as the base. These bye-laws are made applicable to the building activity and development work on lands within the jurisdiction of municipal councils. 
These bye-laws and Development Control rules govern the following aspects

- Building permission

- Zoning

- Sub-division of Land

- Land use, open space, built-up area and height limitation.

- Floor space index

- Lighting and ventilation

- Structural design

- Material and method of construction etc.

One of the facets of building construction, namely, controlling and regulating buildings through municipal bye-laws and departmental handbooks received the attention of the panel and a study of these regulatory practices revealed that some of the prevailing methods of construction are outmoded; some designs are overburdened with safety factors and there are other design criteria which, in the light of newer techniques and methodologies, could be rationalized; building bye laws and regulations of municipal bodies which largely regulate the building activity in the country wherever they exist, were outdated. They did not cater to the use of new building materials and the latest development in building designs and construction techniques. It also became clear that these codes and bye-laws lacked uniformity and they were more often neither 'specification oriented' nor 'performance oriented'. [3]

Due to lack of law enforcement and monitoring, people also violated the plans during the construction stage of their building and structure. There is no other alternative than maintaining the planning standards and managing the city as per the plan to make the city habitable. Success of any law depends on its proper implementation. [4]

The problems arise when the standard rules and regulations intended for guiding the growth of town, to ensure adequate public services, health and safety measures are being violated at large scale.

People need to recognize that law infringements and disregard of city's town planning and building control regulations often lead to depletion of limited resources to provide basic services to the residential area. Any construction which happens without following proper town planning processes will have a negative impact on the provision of, sewerage, water and electricity supply to residents in the neighboring areas. [5]

The magnitude of the problem is high and can not be solved by demolition/forcible action alone. Even though no scientific survey has been carried out, it was reported that a hurried sample survey conducted by MCD recently suggests that in about $60-70 \%$ of the residential units, some portion(s) of the building could be unauthorized and/or in violation of the permissible use. [6]

Lack of statutory authority to initiate action against officers erring in sanctioning plans seems to be one of the detriments in checking building bye-law violations. According to officials in the Palika, the blame for such violation cannot be put on a single person.[7]

The state government recently amended Section $76 \mathrm{~F}$ of the Karnataka town and country planning (KTCP) Act to hold the officials who sanctioned building plans responsible for any such violations. [8]

Building regulations permission is entirely separate from planning permission. Building regulations are the minimum standards that the building work must comply with. They don't control everything but concentrate on health, safety, energy conservation, access to and use of buildings. Others aspects such as the general quality of work are not specifically controlled by building control. [9]

National building code prepared by the Bureau of Indian standards in 1970 and subsequent revisions are advisory in nature but are not mandatory.

NBC is now a national instrument that will regulate the construction activity. It contains all the important aspects relevant for safety and orderly development. The building that does not comply with the Building Code and which violates the NBC will be penalized or the approval will be cancelled or the building will even be demolished. [10]

Public bodies like municipal councils are responsible to control the rapid development with limited resources which necessitates the applications of new practices and technologies like geographic information system.[11]

One of the interesting advances arising from the use of the computer and from electronic gathering, transmission and storage of data is the development of systems of real-time information. This is information about what is happening even while it is happening. It is technically possible through various means to obtain real-time data on many operations. It is means of getting real time control in areas of importance to the project managers. The sooner managers know that activities for which they are responsible are not proceeding in accordance with plan, the faster they can take action to make correction. [12]

The building construction or development is highly technical and specialized branch. The municipal council being a planning authority is adequately invested with the power to take drastic and coercive measures to enforce the compliance of the provisions of the acts, rules and bye-laws. Sub-section (5) of section 189of the 
Maharashtra municipalities act, 1965 authorizes the council to revoke the permission already granted. Subsection (8) authorizes the Chief Officer to stop the construction, if it is in contravention. Sub-section (9) provides that in case of breach by a person, (on conviction) he be punished with a fine. Sub- section (11) authorizes the council to demolish or issue orders for alternation in the building. Sub-section (12) empowers the Chief Officer to make inspection at any time during construction and if it is noticed to be in contravention either of the provisions or bye-laws, he can order to amend. The Act of 1965 thus maintains a complete domain over the building activity in the municipal limits. It further provides a coercive measure for compliance of the provisions.[13,15]

The act of 1965, by section 308, empowers the Collector to suspend execution of any order of the municipal council which is likely to cause injury or annoyance to the public or is against the public interest. Section 318 authorizes the state government to satisfy itself as to the legality or propriety of any order passed by the council. The provision further authorizes the state government to vary or reverse the order after giving a notice to the interested party. Section 320 further empowers the state government and director to take a suto motu review of their order.[13,15]

As regards construction of building or development on land, the scheme of the Act of 1966 is analogous to that under Act of 1965. Section 51 to 56 of the Maharashtra regional and town planning, act of 1966, to enforce compliance of provisions and bye-laws, authorize the municipal council to grant authority to revoke or modify the permission and also to impose penalty, remove, discontinue or stop if the development or construction is unauthorized.[14,15]. It is thus explicit that planning authority is adequately armed with strong legal frame work for guiding the development of a town and to strictly implement the building bye-laws and development control rules.

In spite of such a strong legal frame work available with planning and development authority, development control rules are found to be violated at large scale.

In the present case study, "B" \& "C" class municipal council of Yavatmal district (India) has been taken for critical evaluation of the urban development scenario \& to know the quantum of building bye-laws and development control rules which are violated largely and reasons thereof. Recommendations are framed for reduction in percentage violation and illustrate the range of direction possible to innovate the existing regulation. Area under case study is shown in Fig. 1:

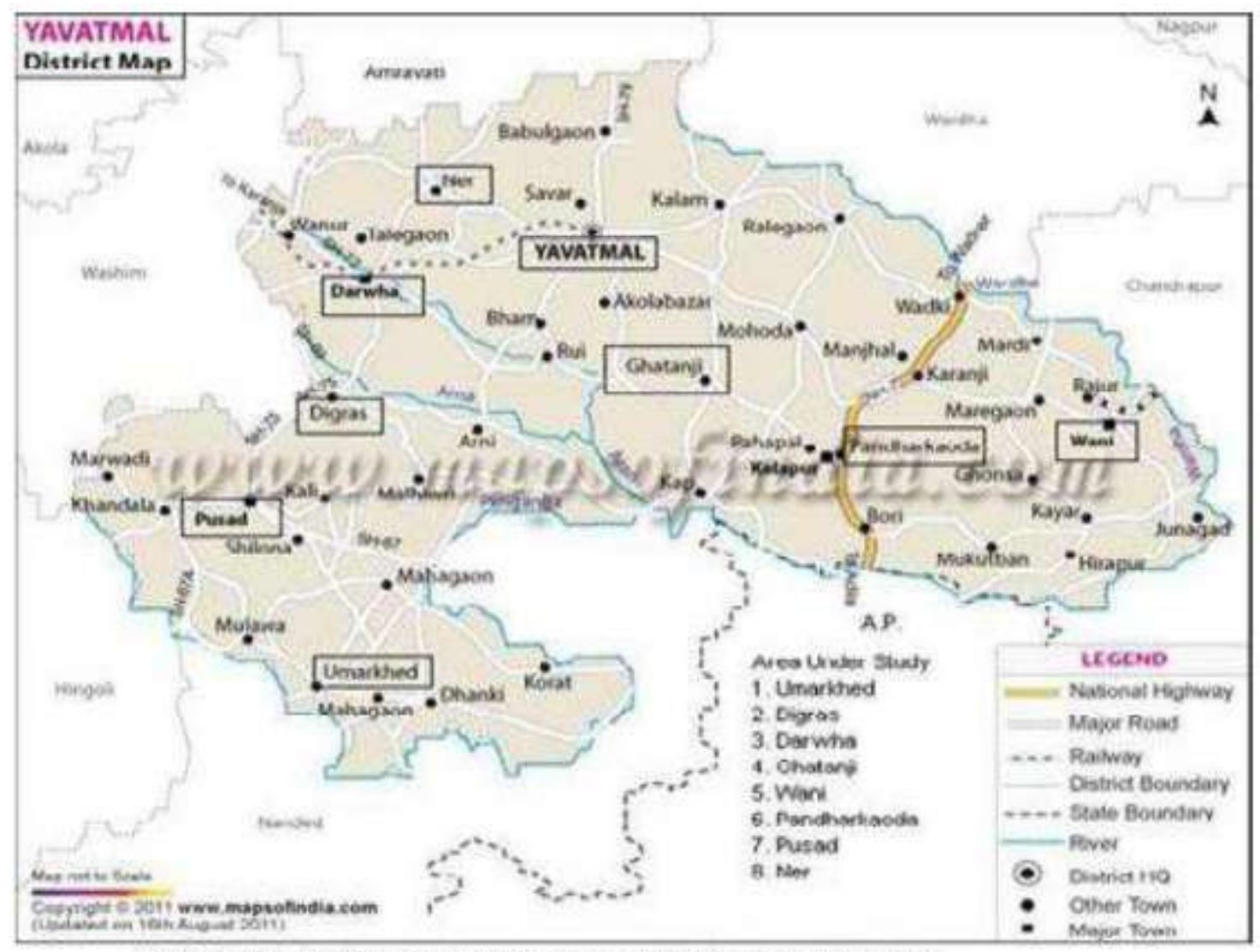

Mapt: Yavatnal district map showing various municipal councis understudy 
II. Methodology:

The aim of this case study was to identify various development control rules which are being violated. This study was conducted in eight municipal towns of Yavatmal district of Maharashtra state( India). Sector wise random field survey was conducted in different areas of the town both in congested and non congested areas. Personal interviews of house owner, Chief Officers, councilors, municipal engineers and eminent personalities were also conducted.

They were questioned regarding adoption of development control rules and their violation and consequent impact on over-all development of the town. Based on literature survey, opinion from experts and own findings from primary and secondary survey, comprehensive three-tier real time information and control system and 'violation reducing mechanism' are proposed.

\section{Over Views of Existing Rules and Bye-Laws [16]:}

Development control rules which are framed for ' $\mathrm{B}$ ' \& ' $\mathrm{C}$ ' class municipal councils of Maharashtra state normally have been violated by and large are mentioned below.

Rule 3.1 Building permit required prior to start of any work/ development work.

Rule 4.1 Every person who intends to carry out development work shall inform in writing to planning authority of such intention in the prescribed form.

Rule 5.1 Every person giving notice referred under rule No. 4 shall submit there with certificate by qualified architect / engineer who shall undertake supervision in the prescribed form along with ownership and planning documents.

Rule 11.1 \& 11.2 For the purpose of facilitating inspection by the authority the following shall be recognize stages in the construction of any building

i. $\quad$ Digging of foundation

ii. Construction of super structure above plinth and planning authority is competent to inspect the building to satisfy that construction is not inconsistent with the permission of the act of rule

Rule 12.1 Every person executing a building shall, within one month after completion of such building shall give written notice to the authority through qualified architect / engineer regarding completion of work in prescribed form.

Rule 13.1 With in a period of 30 day after receipt of such completion notice authority shall communicate in the prescribed form to occupy the building.

Rule 14.1 Speaks about offence of penalties

Rule 19.1, 19.2 Provides rules for land sub- division layout and open spaces in layout.

Rule 20.1 Provides for land use classification, open spaces, area and height limitations.

Rule20.2 and 20.3 Side margins and FSI: Rule20.2and 20.3 represents the side margin to be provided with respect to plot size and width of road in congested and non-congested are as shown as Table 1

Table1: Regulation for Development outside congested area \& within congested area

\begin{tabular}{|c|c|c|c|c|c|c|c|}
\hline \multirow[t]{2}{*}{$\begin{array}{l}\text { Sr. } \\
\text { No. }\end{array}$} & \multirow[t]{2}{*}{$\begin{array}{l}\text { Category \& Road width \& } \\
\text { description of housing }\end{array}$} & \multirow{2}{*}{$\begin{array}{l}\text { Minimum } \\
\text { size of plot } \\
\text { fronting on } \\
\text { road(sq. m.) }\end{array}$} & \multirow[t]{2}{*}{$\begin{array}{l}\text { Minimum set-back } \\
\text { from the road side } \\
\text { (m) }\end{array}$} & \multicolumn{2}{|c|}{$\begin{array}{l}\text { Minimum } \\
\text { marginal } \\
\text { distances }(\mathrm{m})\end{array}$} & \multirow[t]{2}{*}{$\begin{array}{l}\text { Maximum } \\
\text { built up } \\
\text { area }\end{array}$} & \multirow[t]{2}{*}{$\begin{array}{l}\text { No. of } \\
\text { storey's }\end{array}$} \\
\hline & & & & Rear & side & & \\
\hline 1. & $\begin{array}{l}\text { National Highways, State } \\
\text { Highways, Major District } \\
\text { Roads }\end{array}$ & 450 & $\begin{array}{l}25 \mathrm{~m} \text {. form the } \mathrm{C} / \mathrm{L} \\
\text { of the road (existing } \\
\text { or proposed) or } 4.5 \\
\mathrm{~m} \text {. from the road } \\
\text { boundary whichever } \\
\text { is more }\end{array}$ & 4.5 & 3.0 & $1 / 3$ & 3 \\
\hline 2. & Other road above $8 \mathrm{~m}$. & Above 300 & 4.5 & 3.0 & 2.25 & $1 / 3$ & 3 \\
\hline 3. & Below $18 \mathrm{~m}$. & Above 150 & 3 & 1.5 & 1.5 & $1 / 2$ & 2 \\
\hline 4. & Below $18 \mathrm{~m}$. & Above 100 & 3 & 1.5 & $\begin{array}{l}1.5 \\
\text { (only } \\
\text { one } \\
\text { side) } \\
\end{array}$ & $1 / 2$ & 2 \\
\hline 5. & Row housing below $12 \mathrm{~m}$. & Above 50 & 2.25 & 2.25 . & Nil & $1 / 2$ & 2 \\
\hline
\end{tabular}


Violation Of Building Bye-Laws And Development Control Rules: A Case Study

\begin{tabular}{|l|l|l|l|l|l|l|l|}
\hline 6. & Row housing LIG & 30 &.. &.. &.. & $3 / 4$ & 2 \\
\hline 7. & Group housing Scheme &.. & $5 . \mathrm{m}$. from main road & 3.0 & 2.25 & $1 / 3$ & 2 \\
\hline & & $3 \mathrm{~m}$. from path way. & 3.0 & 3 & $1 / 3$ & 3 \\
\hline \begin{tabular}{l} 
Regulation for congested area. \\
\hline
\end{tabular} & $\begin{array}{l}\text { Street 7.5 m. to less than } \\
12 \mathrm{~m} .\end{array}$ & -- & $1.0 \mathrm{~m}$. & -- & - & $75 \% / 60 \%$ & $2 / 3$ \\
\hline 2. & $\begin{array}{l}\text { For Street 12 m. and } \\
\text { above }\end{array}$ & -- & $1.5 \mathrm{~m}$. & -- & - & $-75 \% / 60 \%$ & $2 / 3$ \\
\hline 3. & \begin{tabular}{l} 
For Street less than 7.5 m. \\
\hline
\end{tabular} & -- & No set back & -- & - & $75 \% / 60 \%$ & $2 / 3$ \\
\hline
\end{tabular}

\section{Observations:}

On the basis of primary and secondary survey conducted, the following major violations are observed. (i) Violation of Land subdivision and layouts:

Development plans are one of the planning instruments for framing and implementing the planning policies. Accordingly the existing residential area and the area which has been proposed in the development plans for accommodating future population of various municipal towns of Yavatmal district are shown in Table No. 2.

Table 2: Proposed land use [17-24]

\begin{tabular}{|c|c|c|c|c|c|c|}
\hline \multirow[t]{2}{*}{ Sr. No } & \multirow[t]{2}{*}{$\begin{array}{l}\text { Municipal Town } \\
\text { under study }\end{array}$} & \multicolumn{3}{|c|}{$\begin{array}{l}\text { Total No. of Sectors for planning by } \\
\text { zoning }\end{array}$} & \multirow{2}{*}{$\begin{array}{l}\text { Existing } \\
\text { Area Under } \\
\text { Residential } \\
\text { Zone }\end{array}$} & \multirow{2}{*}{$\begin{array}{l}\text { Proposal } \\
\text { area under } \\
\text { residential } \\
\text { zone }\end{array}$} \\
\hline & & $\begin{array}{l}\text { Congested } \\
\text { Sector }\end{array}$ & $\begin{array}{l}\text { Non } \\
\text { Congested } \\
\text { Sector }\end{array}$ & Total & & \\
\hline 1. & Wani & 02 & 02 & 04 & 112.81 & 271.39 \\
\hline 2. & Darwha & 01 & 01 & 02 & 69.694 & 145.66 \\
\hline 3. & Ghatanji & 01 & 02 & 03 & 125.24 & 207.30 \\
\hline 4. & Digras & 01 & 03 & 04 & 186.25 & 317.70 \\
\hline 5. & Pusad & 01 & 05 & 06 & 107.42 & 378.44 \\
\hline 6. & Umarkhed & 01 & 02 & 03 & 61.57 & 182.94 \\
\hline 7. & Pandharkawda & 01 & 02 & 03 & 61.13 & 396.60 \\
\hline 8. & Ner (Nawabpur) & 1 & 0 & 01 & 122.415 & 290.12 \\
\hline
\end{tabular}

It is very clear from Table 2 that while preparing development plan the agriculture land available within municipal council jurisdiction has also been made available as residential zone by way of zoning proposal. This has given a lot of opportunities to the land owners, builders and developers to develop the lands by converting it's used and sub- division of lands from the respective authorities. These land use change orders are passed with certain mandatory conditions.

A random field survey was conducted to evaluate the implementation of mandatory conditions mentioned in 'land use change orders' and a very significant and expected result of violation of conditions was found. Ten non agriculture order / town passed during the span of 1986 to 2011 (25year) in each town of Yavatmal district has been considered for this survey.

The major conditions which are found violated are:

The roads, drains, culverts were not constructed by the owner / developers as per the standard specification of the local authority and they vested with the local authority for further maintenance. $70 \%$ violation was observed in this survey.

The random field survey reveals that $75 \%$ of open spaces in such layouts were not developed as required.

Some open spaces were found encroached by hawkers, slum dwellers and few became domestic waste disposal sites. $35 \%$ of the sanction layouts are found fully occupied. $60 \%$ of layouts/ plots are holded by investors.

Town wise percentage violation of land use change orders is shown in table 3 . 
Violation Of Building Bye-Laws And Development Control Rules: A Case Study

Table 3: percentage violation of land use change orders

\begin{tabular}{|l|l|l|l|}
\hline \multirow{2}{*}{ Sr. No. } & Name of town & \% Violation \\
\cline { 3 - 4 } & & $\begin{array}{l}\text { Development of Open } \\
\text { Space }\end{array}$ & $\begin{array}{l}\text { Development of Roads } \\
\text { culverts drains }\end{array}$ \\
\hline 1. & Wani & $75 \%$ & $73 \%$ \\
\hline 2. & Darwha & $80 \%$ & $65 \%$ \\
\hline 3. & Ghatanji & $85 \%$ & $75 \%$ \\
\hline 4. & Digras & $75 \%$ & $75 \%$ \\
\hline 5. & Pusad & $65 \%$ & $60 \%$ \\
\hline 6. & Umarkhed & $75 \%$ & $70 \%$ \\
\hline 7. & Pandharkawada & $68 \%$ & $65 \%$ \\
\hline 8. & Ner(Nawabpur) & $80 \%$ & $75 \%$ \\
\hline
\end{tabular}

\section{ii) Violation in plan permission and in execution stage:}

Study from the municipal records reveals that in $90 \%$ cases, certificate of architect / engineer who shall undertake supervision of the construction was not attached in spite of specific condition in rule 5.1 (g) but plans have been approved by the municipal council. Study also points out that, the inspection by the planning authority at various stages during the construction has never been carried out as mentioned in rule no 11.1 and 11.2. On complaint either by the neighbor or by any citizen this practice is found to be adopted.

\section{iii) Violation of Setbacks and FSI}

A major problem of plan violation has been found in the residential construction in congested and non congested areas in all the towns of the district. The Land owners take the building permission from the municipal council by submitting the building plan as per prevailing development control bye-laws and rules and get approval of their plan from the municipal council.

Such approved plans are physically studied with actual constructions.

846 constructed houses were surveyed. Selection of houses was based on random sample basis. This distribution is shown in table 4 . Out of 846 houses $30.73 \%$ houses were constructed on plot size ranging from 50 sq.mt to 100 sq.mt $.30 .73 \%$ are on 100 to 150 sq.mt $27.89 \%$ houses were constructed on 151 to 250 sq.mt plot and $10.64 \%$ were on 251 to 400 sq.mt . These houses were tested for rule 20.2 and 20.3 regarding side margin, front margin, rear margin and floor space index and verified with sanctioned drawing /plan by respective municipal council.

Table 4: Town wise, sector wise house survey

\begin{tabular}{|c|c|c|c|c|c|c|}
\hline \multirow[b]{2}{*}{ Sr. No } & \multirow[b]{2}{*}{ Name of Town } & \multirow[b]{2}{*}{ Sector Number } & \multicolumn{4}{|c|}{$\begin{array}{l}\text { Number of houses under study (Random sample } \\
\text { basis) }\end{array}$} \\
\hline & & & $\begin{array}{l}50-100 \\
\text { Sq.mt }\end{array}$ & $\begin{array}{l}100-150 \\
\text { Sq.mt }\end{array}$ & $\begin{array}{l}151-250 \\
\text { Sq.mt }\end{array}$ & $\begin{array}{l}251-400 \\
\text { Sq.mt }\end{array}$ \\
\hline \multirow{4}{*}{1} & \multirow{4}{*}{ Wani } & 1 & 10 & 10 & 10 & 3 \\
\hline & & 2 & 10 & 10 & 10 & 3 \\
\hline & & 3 & 10 & 10 & 8 & 3 \\
\hline & & 4 & 10 & 10 & 8 & 1 \\
\hline \multirow{2}{*}{2} & \multirow{2}{*}{ Darwha } & 1 & 10 & 10 & 10 & 5 \\
\hline & & 2 & 10 & 10 & 8 & 5 \\
\hline \multirow{3}{*}{3} & \multirow{3}{*}{ Ghatanji } & 1 & 10 & 10 & 10 & 5 \\
\hline & & 2 & 10 & 10 & 10 & 5 \\
\hline & & 3 & 10 & 10 & 8 & 5 \\
\hline \multirow{4}{*}{4} & \multirow{4}{*}{ Digras } & 1 & 10 & 10 & 10 & 2 \\
\hline & & 2 & 10 & 10 & 10 & 2 \\
\hline & & 3 & 10 & 10 & 8 & 2 \\
\hline & & 4 & 10 & 10 & 8 & 4 \\
\hline
\end{tabular}


Violation Of Building Bye-Laws And Development Control Rules: A Case Study

\begin{tabular}{|c|c|c|c|c|c|c|}
\hline \multirow{6}{*}{5} & \multirow{6}{*}{ Pusad } & 1 & 10 & 10 & 10 & 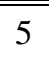 \\
\hline & & 2 & 10 & 10 & 10 & 5 \\
\hline & & 3 & 10 & 10 & 10 & 5 \\
\hline & & 4 & 10 & 10 & 8 & 5 \\
\hline & & 5 & 10 & 10 & 8 & 5 \\
\hline & & 6 & 10 & 10 & 8 & 5 \\
\hline \multirow{3}{*}{6} & \multirow{3}{*}{ Umarkhed } & 1 & 10 & 10 & 10 & 3 \\
\hline & & 2 & 10 & 10 & 10 & 3 \\
\hline & & 3 & 10 & 10 & 8 & 3 \\
\hline \multirow{3}{*}{7} & \multirow{3}{*}{ Pandharkawada } & 1 & 10 & 10 & 10 & 2 \\
\hline & & 2 & 10 & 10 & 10 & 2 \\
\hline & & 3 & 10 & 10 & 8 & 2 \\
\hline \multirow[t]{2}{*}{8} & Ner & 1 & 10 & 10 & 8 & 5 \\
\hline & Total & 26 & 260 & 260 & 236 & 90 \\
\hline
\end{tabular}

Findings of the study are very surprising:

- Road side margin, side margin and rear margin are found violated both in congested and non congested areas.

- Set back violation is shown in Table 5

- Floor space index has also been found violated because of excessive coverage on the ground floor

- $68.27 \%$ and $67.86 \%$ violation is found for left and right sides margin of the plot.

- $56.60 \%$ violation is found for front margin.

- $63.83 \%$ violation observed to the back side margin.

- $74.82 \%$ violation of floor space index is observed.

Fig. 2 shows that up to 150 square meter plot area violation of setback is above $80 \%$ and it gradually decreased up to $60 \%$ as plot size increases. For front margin trend of violation is higher for a smaller plot size but it is lower in case of larger plot size. Study also points out that the floor space index violation is $100 \%$ for plots size up to 100 to 150 square meters and onward violation percentage reduces gradually which is shown in Fig. 3.

It is found that owners/developers have sanctioned their plans from respective municipal councils but these approved plans do not match with actual construction, with reference to planning provisions like location of rooms, door and window Positions and their physical appearance (elevation). For plot size up to 100 square meter violation in physical plan provision was found to be $15 \%$, however this violation percentage gradually increased to $55 \%$ for larger plot sizes.

Though it was mandatory to submit completion certificate through qualified architect and get occupancy certificate, it is observed that neither the completion certificate was submitted to council nor the council has issued occupancy certificates Fig. 4 shows the trend of violation of physical plan provision, violation of rule 5.1g. and rule 12.1

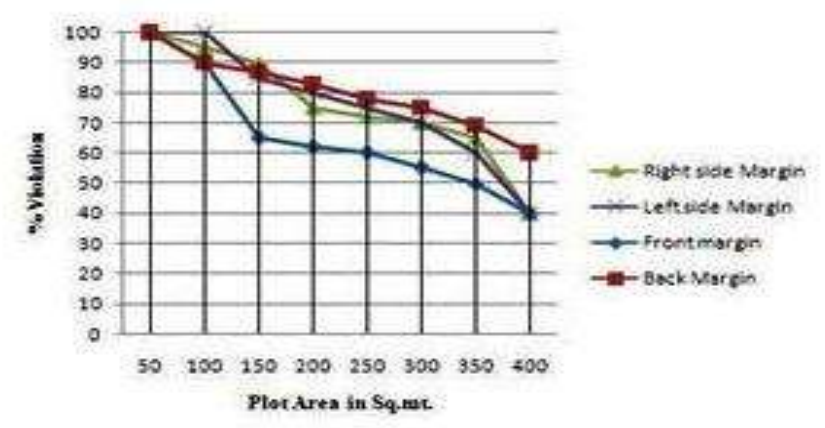

Fig.2: Plot Area Vs Violation of setback 


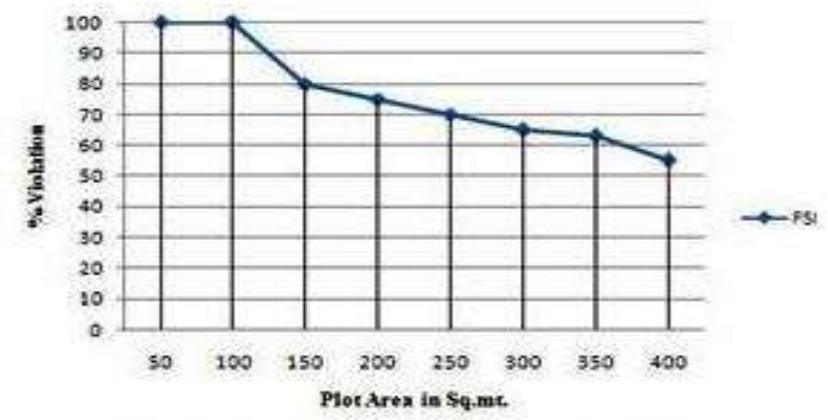

Fig. 3: Plot Area Vs Violation of FSI
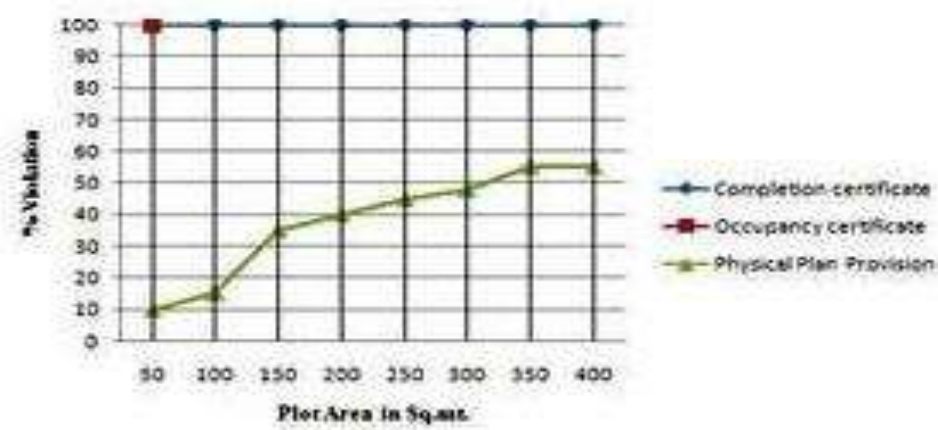

Fig.4: Plot Area Vs Violation of Physical Plan Provision

Table 5: \% violation of side margins, front \& Rear margin, F.S.I.

\begin{tabular}{|c|c|c|c|c|c|c|c|c|}
\hline \multirow[b]{2}{*}{$\begin{array}{l}\text { Sr. } \\
\text { No }\end{array}$} & \multirow[b]{2}{*}{ Town } & \multirow{2}{*}{$\begin{array}{l}\text { Secto } \\
\mathrm{r}\end{array}$} & \multicolumn{4}{|c|}{ Set Back Violation \% } & \multirow{2}{*}{$\begin{array}{l}\text { F.S.I.Violation } \\
\%\end{array}$} & \multirow[b]{2}{*}{ Remark } \\
\hline & & & $\begin{array}{l}\text { Left } \\
\text { Margin }\end{array}$ & $\begin{array}{l}\text { Right } \\
\text { Margin }\end{array}$ & $\begin{array}{l}\text { Front } \\
\text { Margin }\end{array}$ & $\begin{array}{l}\text { Rear } \\
\text { Margin }\end{array}$ & & \\
\hline \multirow{4}{*}{1} & \multirow{4}{*}{ Wani } & 1 & 80 & 78 & 51 & 38 & 80 & \\
\hline & & 2 & 80 & 85 & 90 & 90 & 75 & Congested \\
\hline & & 3 & 70.5 & 65.5 & 40 & 78 & 45 & \\
\hline & & 4 & 80 & 85 & 92 & 95 & 100 & Congested \\
\hline \multirow{2}{*}{2} & \multirow{2}{*}{ Darwha } & 1 & 66.4 & 67.5 & 35 & 70 & 80 & \\
\hline & & 2 & 62.3 & 66.5 & 32 & 68 & 78 & \\
\hline \multirow{3}{*}{3} & \multirow{3}{*}{ Ghatanji } & 1 & 78.3 & 76.2 & 80 & 83 & 76 & Congested \\
\hline & & 2 & 58.5 & 65.5 & 45 & 52 & 78 & \\
\hline & & 3 & 65.6 & 70.5 & 38 & 48 & 82 & \\
\hline \multirow{4}{*}{4} & \multirow{4}{*}{ Digras } & 1 & 72.5 & 63.5 & 45 & 48 & 55 & New Area \\
\hline & & 2 & 65.3 & 55.55 & 42.5 & 46.5 & 65 & New Area \\
\hline & & 3 & 71.3 & 65.5 & 38.5 & 33.5 & 50 & \\
\hline & & 4 & 78.5 & 75.3 & 80 & 82 & 100 & Congested \\
\hline \multirow{6}{*}{5} & \multirow{6}{*}{ Pusad } & 1 & 72.5 & 71.5 & 75.3 & 78.5 & 100 & Congested \\
\hline & & 2 & 45 & 39.5 & 35 & 45 & 70 & New Area \\
\hline & & 3 & 49.5 & 46.5 & 33.5 & 41.5 & 70 & \\
\hline & & 4 & 56.5 & 60.3 & 30.5 & 40.5 & 65 & \\
\hline & & 5 & 66.5 & 63.5 & 40.5 & 50 & 57 & \\
\hline & & 6 & 51.5 & 55.5 & 38.5 & 56.50 & 86 & \\
\hline \multirow{3}{*}{6} & \multirow{3}{*}{ Pandarkawda } & 1 & 80 & 81.5 & 78.5 & 75.5 & 100 & Congested \\
\hline & & 2 & 48.5 & 46.5 & 30.5 & 46.5 & 73 & \\
\hline & & 3 & 51.5 & 56.5 & 38.2 & 36.5 & 100 & \\
\hline \multirow{3}{*}{7} & \multirow{3}{*}{ Umarkhed } & 1 & 81.5 & 85.5 & 86 & 83 & 100 & Congested \\
\hline & & 2 & 85.3 & 86.5 & 78.5 & 90 & 100 & \\
\hline & & 3 & 78.5 & 80.5 & 75.5 & 90.5 & 85 & \\
\hline \multirow[t]{2}{*}{8} & Ner (Nawabpur) & 1 & 73.2 & 75 & 80 & 80.5 & 75 & Congested \\
\hline & \multicolumn{2}{|c|}{ Average percentage } & 68.23 & 67.86 & 56.60 & 63.83 & 74.82 & \\
\hline
\end{tabular}


iv) Validity of Existing rules

Standardized building bye-laws and development control rules are framed and made applicable in Maharashtra state from $2^{\text {nd }}$ April 1974 and thereafter minor modifications were made from time to time in general. Unfortunately floor space index which is an important factor to accommodate future population has never been revised in proportion to population growth rate.

The study points out that the population growth of the town has increased with an average rate of $2.4 \%$ per annum for all municipal town of Yavatmal district but rules have not been modified since 1974, and moreover only horizontal expansion has been permitted through development plan zoning proposals, it results in conversion of fertile agriculture land to non agriculture land largely.

\section{Causes Of Violation:}

To find out causes of the violation, an opinion survey of citizens (house owner), selected on random sample basis through structured questionnaire was carried out.. Survey reveals that $85 \%$ of the public are of the opinion that this violation is due to very high cost of land and $10 \%$ feel that it is because of administrative negligence. $05 \%$ were unaware of such violations.

A detailed discussion with chief officers, municipal engineers of all the municipal town under study has been done and they are of the opinion that lack of monitoring machinery, shortage of technical manpower at the municipal level are the major concern of the municipal councils to control and avoid such violations from its occurrence. Some also feel that the local political influence is also a hurdle in controlling such violations. Static nature of development control rules for a longer period is also contributing to the violation trend. Real time information and control system as suggested in figure 5 and violation reducing mechanism as shown in figure 6 were also discuss with the officers. They have given consent and opined that suggested models will help in controlling the violation trend.

\section{Recommendations:}

i. Different rules are framed for congested and non congested areas within the jurisdiction of the municipal councils.[16] Congested areas were developed 40 to 50 years back and are still deprived of essential amenities. While granting new building permission in congested areas rules and regulation of non congested area should be made applicable. This is required for making the congested area into a non congested area in future, otherwise congested area shall remain congested ever and the people living in this area will be deprived of breeze, light, ventilation and smooth transportation on street etc.

ii. Vertical expansion is promoted by increasing the floor space index incrementally with proportion to population growth periodically in identified areas. This will control the horizontal expansion of town and thereby reducing conversion of agricultural (fertile) land into non agricultural land.

iii. Assessment and audit of already sanctioned layout in terms of its occupancy is the necessity of the hour. Unless and otherwise the population density reaches the desired level, no further horizontal expansion be allowed by way of permitting land use change. This restriction is necessary to protect agricultural land within municipal boundary.

iv. Traditional tools of framing the development plan proposals in respect of zoning be changed and a method of regulating development to achieve a specific urban form shall be provided. Development control rule shall be made such that maximum number of dwelling units can be accommodated in the available piece of land to optimize the use of land without affecting adversely the quality of urban life and to save agriculture land. More focus on environment and resources like urban water bodies forest and bio diversity be made so as to shape a city towards sustainable development.

v. Removal of provision of sec 28.2 : As per Sec. 28.2“The director of town planning may permit special relaxation to any bye-law provided the relaxation does not affect the health, safety, fire safety, and structural safety, public safety of the inhabitants, the buildings and the neighborhood". The fact is that if the director has a special power to relax any rule or bye-law that will contribute a great deal in diluting the sanctity of this act in the eyes of the builder as well as the courts [3].Hence it is recommended to delete the section 28.2 from development control rules and bye-laws.

vi. Provision in section 28.3.1, 3.2, and 3.3 shall be modified and recent trends in construction materials like green building concepts and use of green building material shall be made mandatory in construction" even while granting permission .

vii. Based on literature survey, opinion from experts and own findings from primary and secondary survey a comprehensive three-tier real time information and control system is strongly recommended as shown in figure 5 which will integrate many key activities in a systematic manner and is consciously directed towards the effective and efficient achievement of reducing the violation of building bye-laws and development control rules. Where in, the owner who desire to initiate the development activity has to appoint a qualified consultant for submission of his proposal to the "municipal council cell" comprising of executive engineer, deputy engineer and junior engineer. The municipal council shall also appoint a 
third party registered technical non-government organization consisting of an architect, a civil engineer and a surveyor. The planning proposal received from the owner will be scrutinized in the light of building bye-laws and development control rules and if the proposal is found as per rule, permission for development shall be granted. A third party registered technical non-government organization shall be asked to inspect and submit the report at foundation level, super structure level and completion level to the municipal council. If at any stage, the report of the above organization is adverse the municipal council should immediately issue a notice to stop the work; if required, orders may be issued to demolish the illegal construction. If the construction is as per rule, municipal council should issue occupancy certificate on submission of completion certificate from the architect or engineer appointed by owner. Facilities like water supply, electricity supply, telephone service and aid from financial institutes can only be availed by the owner on producing the occupancy certificate issued by the municipal council. The authorities providing the above facilities should be empowered to inspect the site to satisfy themselves that the construction work is not inconsistent and constructed as per the Act; they can also reject the facility, if any contravention is found, while cross checking at the site.

By this comprehensive system, the deviation may be detected in advance of their occurrence and may be avoided by appropriate and timely action.

To implement this comprehensive three tier real time information and control system effectively and transparently, the municipal council needs to utilize the information technologies such as internet to make available the map submitted and sanctioned by them to the public through this real time approach. Updated information about what is happening while it is happening will be available to all concerned. Through this system public participation will increase to a great extent. The suggested model can become an effective tool for monitoring and controlling the violation of building bye-laws and development control rules.

viii. "Building bye-laws violation control cell" shall be established at municipal council level to make the municipal councils more people-friendly and to make more effective enforcement towards building byelaws violation. By establishment of such cell with wide publicity shall certainly useful to the municipal council to make investigation of complaints regarding violation of building control rules more transparently. Figure 6 shows the violation reducing mechanism where in citizens complaints shall be received to "Building bye-laws violation control cell". These complaints shall be processed immediately and if found guilty notice will be issued to concern violators to stop / remove the unauthorized construction. If the notice is not complied the cell will report with police station for further action as per Maharashtra regional and town planning Act, 1966. In the case of false complaint cell will lodge complaint against complainant.

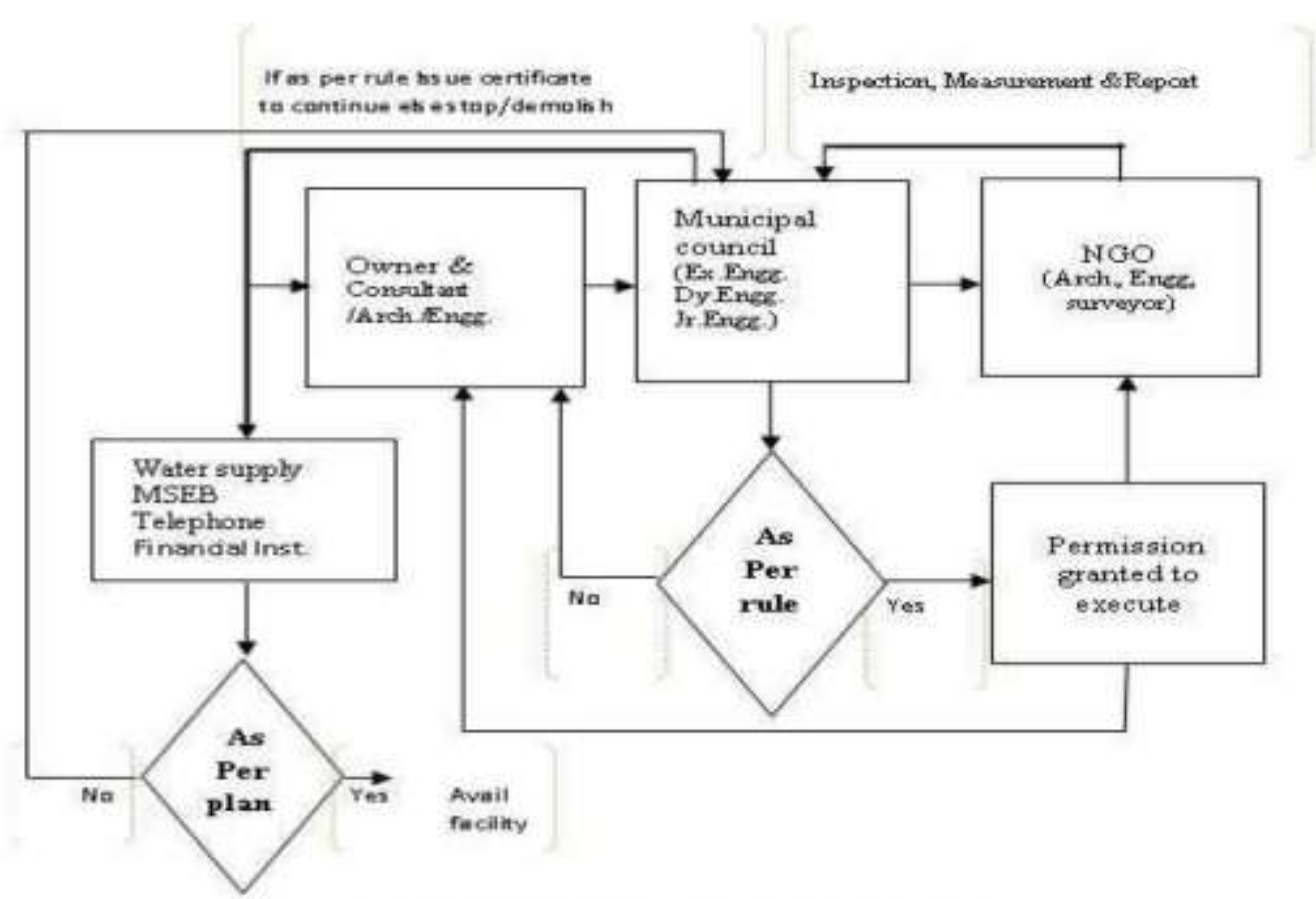

Fig. 5: Real Time Information \& Control System 


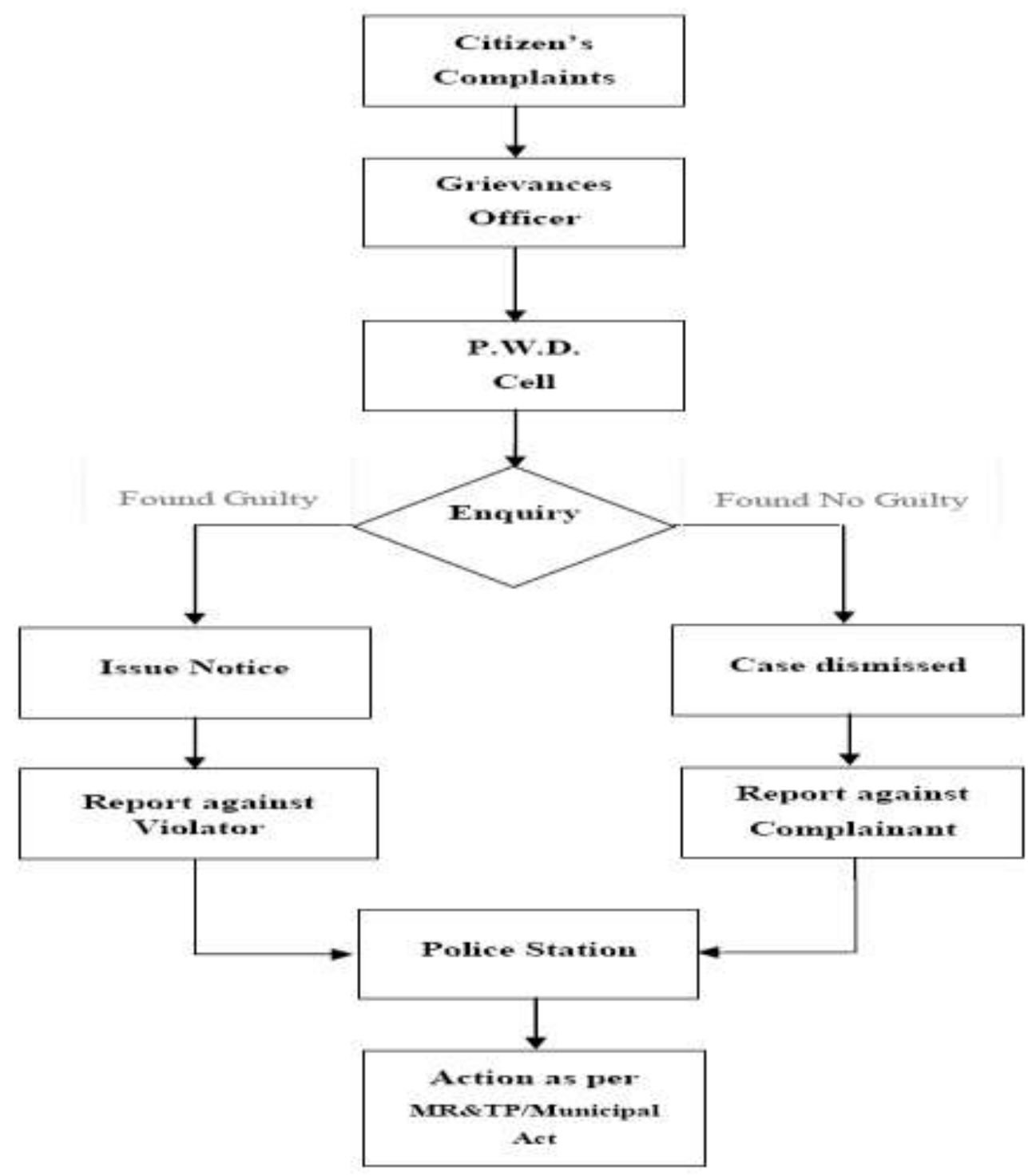

Fig. 6: Violation Reducing Mechanism

\section{Conclusion:}

The rules, regulations and bye-laws are made by the councils or development authorities taking in view the larger public interest of the society and it is the bounden duty of the citizens to obey and follow such rules which are made for their own benefits. If possible, the citizen of the town should self participate in the process of development of town.

Since planning authority is adequately empowered to enforce the act, the rules and bye-laws, need is to strengthen the municipal council with the technical man power and adequate machinery to run the mechanism.

Provision of land through town planning scheme should be carried out to augment the supply of land resources for a balanced development.

A comprehensive three tier real time information and control system and violation reducing mechanism as suggested will strengthen the municipal council in detecting the deviation in the construction in advance of their occurrence and may be avoided by appropriate and timely action. It will also enhance the public participation for controlling building violation.

The present development control rules should also be made dynamic by changing as per the urban development requirement and its validity must be verified periodically.

This will inspire new initiatives \& stimulate debate in the often neglected area of urban development control rules $\&$ regulation for sustainable development. 


\section{References}

[1]. Eran Ben Joseph, "Innovating regulations in Urban Planning and development", Journal of Urban Planning and Development ASCE/December 2005/Pg. 201.www. bmtpc.org

[2]. M. Subash Chandira.”Development control rules and byelaws in Tamilnadu", ITPI Journal 4:1(2007) Pg. 37-43.

[3]. Md. Akter Mahmud, "Corruption in Plan permission process in RAJUK A study of violations and proposals. Aug.2007, www.tibangladesh.org www.joburg.org.za.

[4]. Report of Tajendra Khanna Committee,

[5]. www.urbanindia.nic.in/what'snew/tkc.htm

[6]. Sandeep Moudgal, (News paper editor) Bangalore, (Oct.4-2011, Deccan Herald News)

[7]. Karnataka town and country planning act (Sec.76F)

[8]. http://www.south-derbys.gov.uk/planning and building control/buil.

[9]. National building code. 2005 published by Bureau of Indian Standards www.bis.org.in

[10]. Mubushar Hussain, Kashif Siddiki, "Assessing applicability of GIS as a development management tool at local level: A case study of the city district government, Lahore Pakistan.

[11]. http://www.gisdevelopment.net/application/urban/overview/me05_...

[12]. H. Weihrich, Mark V. Cannice Harold Koontz: "Management: A Global and Entrepreneurial Perspective". McGraw -Hill publication $2008 \mathrm{Pg} .423-424$.

[13]. Maharashtra Municpalties Act. of 1965.

[14]. Maharashtra regional and Town Planning Act. 1966

[15]. Vora Automotives (P) Ltd., Vs Gopal Rao Namdeo Rao Pohare, AIR 1992 Bom. 51:1992 MCC 490.

[16]. "Standardized Building Bye-laws and Development Control Rules for 'B' and 'C' Class Municipal Councils of Maharashtra 1978". Published in govt. gazette.

[17]. Development Plan of Wani, 1991

[18]. Development Plan of Darwha, 2005

[19]. Development Plan of Ghatanji, 2002

[20]. Development Plan of Digras, 1987

[21]. Development Plan of Pusad, 1998

[22]. Development Plan of Umarkhed, 1999

[23]. Development Plan of Pandharkawda, 1997

[24]. Development Plan of Ner (Nawabpur) 1991 